\title{
STILL TRAINING TO TORTURE? US TRAINING OF MILITARY FORCES FROM LATIN AMERICA
}

\author{
Dr Ruth Blakeley \\ School of Politics and IR, University of Kent \\ This is an Author's Accepted Manuscript of an article published in Third World Quarterly, \\ vol.27, no.8, pp. 1439-1461, 2006, copyright Taylor \& Francis, available online at: \\ http://www.tandfonline.com/doi/pdf/10.1080/01436590601027289
}

\begin{abstract}
It is widely assumed that the School of the Americas (SOA), a US training school for Latin American military forces, advocated repression during the Cold War. To demonstrate this, previous research has tended to focus on establishing correlations between training and specific human rights abuses by individuals trained at SOA. A stronger case can be made through detailed analysis of SOA training manuals within the context of US foreign policy towards the global South. Public protest led to SOA's re-launch in 2001. Most protestors assume that this change was purely cosmetic. Based on extensive fieldwork, I argue that changes were genuine, and the School now has a commendable human rights programme. This is in contrast to most US military training, domestic and foreign, which remains secretive and devoid of adequate human rights instruction. The paper argues that a resurgence of support for repression since 9/11 undermines progress at the School.
\end{abstract}

\section{Introduction $^{1}$}

It has been widely assumed that the notorious School of the Americas (SOA), a US training school for Latin American military personnel, established in the 1940s, was a "School of Assassins." The School was re-launched as the Western Hemisphere Institute for Security Cooperation (WHINSEC) in 2001, following massive public protest by SOA Watch (SOAW). SOAW argue that it continues to be a "School of Assassins," that the re-launch was purely cosmetic, and that WHINSEC continues to pose a threat to human rights and should be closed.

I argue that SOA was engaged in advocating repression during the Cold War, but the emphasis in previous research on establishing correlations between incidents of human rights abuses and the involvement in them of individuals who have attended SOA, is misplaced. ${ }^{3}$ I argue that a stronger case can be made by referring to US policy towards the

\footnotetext{
${ }^{1}$ I am grateful to everyone from the US Department of Defence and WHINSEC who agreed to be interviewed, especially Ken LaPlante, Lee Rials and Tony Raimondo; and various members of SOA Watch, especially Roy Bourgeois, Eric LeCompte, Jacqueline Baker, and David Mezzera. Thanks also to the editors of TWQ, Eric Herring, Laura Shepherd, Anna Stavrianakis, Doug Stokes and Stephen Blakeley for comments on earlier drafts of this paper.

${ }^{3}$ J Nelson-Pallmeyer, School of Assassins, New York: Orbis Books, 1997; Second Edition, 2001; K McCoy, 'Trained to Torture: A Statistical Analysis of Human Rights Violations Committed by Graduates of the US Army School of the Americas, 1960-2000', University of Wisconsin, Master of Science Thesis, 2003.
} 
global South, which was characterised primarily by support for repression. ${ }^{4}$ This support for repression is evident in training manuals used at SOA that advocated torture and murder, and in additional training materials used by US security and intelligence agencies during the Cold War. Previous research has referred to the SOA manuals, but no detailed analysis has been undertaken within the context of foreign policy. I have analysed them in conjunction with other security and intelligence materials, and have also interviewed US Department of Defence (DoD) personnel who were involved in the training at SOA and beyond. $^{5}$

Since the re-launch, there has been no detailed research to assess WHINSEC. ${ }^{6}$ Contrary to widespread perceptions, I show that positive changes have taken place. It now has commendable human rights training and a high level of accountability. These findings are based on interviews with DoD personnel, and a two-month period of observation and interviewing at WHINSEC. Meanwhile, the majority of US military training, domestic and foreign, remains unaccountable and is being offered to countries with poor human rights records. Since 9/11, the US has condoned and used repression, particularly in the treatment of "War on Terror" detainees. The question of the effectiveness of US human rights training for its own and other troops is very much in the public eye, following the alleged massacre of Iraqis by US troops in Haditha. In early June 2006, US troops were ordered to take a crash course in battlefield ethics following revelations about the massacre. ${ }^{7}$ It is not clear what this training will entail and how it is envisaged that it will have positive effects on the conduct of US troops. Throughout the paper, the connections between the training and broader patterns in US foreign policy strategy are outlined. I conclude that while SOA and WHINSEC reflected wider strategies prior to 9/11, WHINSEC does not yet reflect the most recent shift in US foreign policy strategy, which amounts to a resurgence of support for repression.

\section{SOA, counterinsurgency and repression}

US strategies for achieving foreign policy objectives during the Cold War in the South were predominantly repressive, and justified in terms of containing communism. However, US support for and use of repression throughout the Cold War was as much to do with protecting and promoting the interests of US and international capitalist elites as with

\footnotetext{
${ }^{4} \mathrm{My}$ interpretation of the terms human rights and repression are drawn from two bodies of international law: International Humanitarian Law (IHL) and International Human Rights Law (IHRL). Human rights are those rights which all citizens share under international law, both in peacetime and during armed conflict, and which are to be guaranteed by armed actors with regard to IHL, and by the state and armed actors with regard to IHRL. The most fundamental of these are the right to life, the prohibition of torture or cruel, inhuman or degrading treatment or punishment, prohibition of slavery and servitude and the prohibition of retroactive criminal laws. In addition to these, human rights comprise the prohibition of discrimination on any basis, provisions for the protection of women and children, and the regulation of aspects of health and food provision, as well as labour. I define repression as any act which violates these human rights laws. See ICRC, 'International Humanitarian Law and International Human Rights Law: Similarities and Differences', International Committee of the Red Cross, 2003,

<http://www.icrc.org/Web/Eng/siteeng0.nsf/htmlall/57JR8L/\$FILE/IHL_and_IHRL.pdf?OpenElement> I use the terms "coercion" and "repression" interchangeably.

${ }^{5}$ Lesley Gill undertook an anthropological study at SOA, and analysed the way in which the training is intended to shape the Latin American militaries in accordance with US foreign policy objectives, by focusing on the interactions between staff and students at SOA in the late 1990s. See: L Gill, The School of the Americas. Military Training and Political Violence in the Americas, Durham: Duke University Press, 2004, which is the only work to date which has involved interviews with those involved with the training.

${ }^{6}$ Amnesty International's research on the extent of US training of foreign military personnel included a brief section which commented on the improved transparency and introduction of human rights training at WHINSEC. AI, 'Unmatched Power, Unmet Principles: The Human Rights Dimensions of US Training of Foreign Military and Police Forces', Amnesty International, 2002,

<http://www.amnestyusa.org/stoptorture/msp.pdf>

7 J Borger, 'US Troops Ordered to Undergo Ethical Training after Killing of Iraqi Civilians', The Guardian, 2 June 2006, <http://www.guardian.co.uk/print/0,,329495232-103550,00.html>
} 
containing communism. ${ }^{8}$ The US state supported the use of torture and murder by CIA and military personnel in Vietnam under the Phoenix Programme, and backed coups and repression by authoritarian governments, in which many thousands of civilians have been killed. ${ }^{9}$ During the Cold War Counterinsurgency (CI) strategies dominated US military training, which advocated operations to undermine supposed guerrilla activity, to the detriment of human rights. ${ }^{10}$ The charge that the training has contributed to repression has most frequently been levelled against SOA, responsible for training 61,000 Latin Americans between 1946 and 2000. SOAW argue that the training has resulted in systematic repression by SOA graduates. SOA's 1962 mission statement indicates the centrality of $\mathrm{CI}$ to its curriculum:

Every course taught has definite application in the CI field [...] Currently, the Department provides instruction in every aspect of CI operations, be it military, paramilitary, political, sociological or psychological. ${ }^{11}$

Whilst there is compelling evidence that some SOA graduates were involved in repression, and that the training encouraged this, previous research has not established the relationship between the training and repression as thoroughly as possible. Researchers have tried to prove that the training caused specific individuals to commit acts of repression. ${ }^{12}$ Whilst this is plausible, their findings revolve around a handful of cases in which allegations have been made against individuals who, at some point in the past 50 years, received SOA training. Allegations have been made against less than 1.5 percent of SOA attendees and of those, only nine individuals have actually been found guilty. Of these nine, three were sentenced by Peruvian military courts, and three by civil courts in Argentina, El Salvador and Panama. One Guatemalan was sentenced by a US court, and it is not clear what type of court sentenced the other two, from Peru. ${ }^{13}$ In a climate of impunity, it is amazing that any allegations were made at all, and that anyone was found guilty. In such a climate, people are unlikely to report repression out of fear of reprisals. The incidence of acts of repression committed was probably far higher than previous research suggests. There are more appropriate ways of establishing the relationships between the training and repression, and this involves assessing the nature of the training within the broader context of US foreign policy.

\section{Spanish language manuals: advocating repression}

The US military has been complicit in repression through the use of training materials which advocated human rights violations. These were distributed among SOA students and US Mobile Training Teams (MTTs) for use among Latin American soldiers, and were consistent with materials used by US military and intelligence services during the Cold War. In March 1992, the US Assistant to the Secretary of Defence for Intelligence

\footnotetext{
${ }^{8}$ W Blum, Killing Hope. US Military and CIA interventions since World War II, London: Zed Books, 2003, pp.7-20; N Chomsky and E Herman, The Washington Connection and Third World Fascism: The Political Economy of Human Rights, vol I, Boston: South End Press, 1979, pp.1-40; E Herman, The Real Terror Network, Second Edition, Montreal: Black Rose Books, 1985, pp.1-8; G Kolko, Confronting the Third World. United States Foreign Policy 1945-1980, New York: Pantheon Books, 1988, pp.3-16; D Stokes, America's Other War, London: Zed Books, 2005, pp.18-34; 'Why the End of the Cold War Doesn't Matter: the US War of Terror in Colombia', Review of International Studies, 29(4), 2003, pp.560-585.

${ }^{9}$ On the Phoenix Programme see D Valentine, The Phoenix Program, Second Edition, Lincoln: Authors Guild BackinPrint.Com, 2000. On US involvement via the CIA in coups and repression see Chomsky, and Herman, The Washington Connection; Kolko, Confronting the Third World; Blum, Killing Hope.

${ }^{10}$ For analysis of counterinsurgency as a US foreign policy tool see M McClintock, Instruments of Statecraft, New York: Pantheon Books, 1992.

${ }^{11}$ US Department of Defence, USARCARIB School Supplemental Course Catalogue, 1962, pp.5-7. Cited in J Leuer, 'A Half Century of Professionalism: The US Army School of the Americas', Adelante, Historical Edition, 2000, p.13.

${ }^{12}$ Nelson-Pallmeyer, School of Assassins; School of Assassins: Guns, Greed and Globalisation, Second Edition; and McCoy, Trained to Torture.

${ }^{13}$ SOAW, 'Notorious Graduates (By Country)', School of Americas Watch, 2004, <http://www.soaw.org>
} 
Oversight (ASDIO) presented a report to the Secretary concerning seven Spanish language manuals that were used as part of intelligence training in Latin America and at SOA between 1987 and 1991. ${ }^{14}$ The ASDIO report concluded that six of the manuals "contain about two dozen passages of objectionable and questionable material and that they were prepared without the required doctrinal approval." ${ }^{15}$ They were released following immense Congressional and public pressure in 1996, along with a press release stating, "Two dozen short passages in six of the manuals, which total 1169 pages, contained material that either was not or could be interpreted not to be consistent with US policy."16 These manuals were not an anomaly, but were consistent with CI doctrine that had been circulating since the 1960s among US military and intelligence agencies. ${ }^{17}$ A CIA manual, Interrogation, produced in 1983 using material from the training notes for a CIA course for the Honduran Battalion 316, and from a 1963 manual entitled KUBARK, had been written for use by CIA agents against communist subversion. A further CIA manual, Psychological Operations in Guerrilla Warfare, which instructed Nicaraguan rebels in political assassination and guerrilla warfare, was leaked to the House Intelligence Committee in 1984. ${ }^{18}$ A CIA manual entitled Human Resource Exploitation also contains material which advocates torture during interrogation. ${ }^{19}$

According to Ken LaPlante, WHINSEC's liaison to the Army until 2005, only four of the seven manuals cited in the ASDIO report were distributed to SOA students. ${ }^{20}$ These were Handling Sources, Counterintelligence, Combat Intelligence and Analysis I. LaPlante insisted that they were only issued to those on the Military Training course, offered twice between 1989 and 1991, as additional readings. This amounted to 50 students in total, and he said it could be safely assumed that another 25 , primarily faculty members, also took these materials. ${ }^{21}$ These and the remaining manuals, were, however, used among MTTs, and it is unclear how many more individuals received them. An investigation in 1997 by the Inspector General concluded that retrieval of all the manuals was unlikely to be possible. ${ }^{22}$ Responsibility for the manuals' compilation and use has not been attributed to any particular US officials.

Various passages within the manuals advocate the violation of Article 4 of Protocol II additional to the Geneva Conventions, (henceforth, Article 4) which states:

All persons who do not take a direct part or who have ceased to take part in hostilities, whether or not their liberty has been restricted, are entitled to respect for their person, honour and convictions and religious practices. They shall in all circumstances be treated humanely, without any adverse distinction. It is prohibited to order that there shall be no survivors. Without prejudice to the generality of the foregoing, the following acts against the persons referred to in paragraph I are and shall remain prohibited at any time and in any place whatsoever: (a) violence to the life, health and physical or

\footnotetext{
${ }^{14}$ L Haugaard, 'Declassified Army and Central Intelligence Agency Manuals Used in Latin America: An Analysis of their Content', Latin American Working Group, 1997,

<http://www.lawg.org/pages/new\%20pages/Misc/Publications-manuals.htm>

${ }^{15}$ US Department of Defence, 'Fact Sheet Concerning Training Manuals Containing Materials Inconsistent With United States Policy', Office of the Assistant Secretary of Defence, US Department of Defence, 1992, <http://www.gwu.edu/ nsarchiv/nsa/archive/news/dodmans.htm>

${ }^{16}$ Haugaard, 'Declassified Army and Central Intelligence Agency Manuals'.

${ }^{17}$ Interviews with DoD personnel between June and September 2004 enabled me to trace the development of the Spanish language materials.

${ }^{18}$ J Kennedy, Report on the School of the Americas, Washington DC: National Security Archives, 1996, pp.120.

${ }^{19}$ CIA, Human Resource Exploitation Manual, Washington DC: Central Intelligence Agency, 1982, Manual acquired by National Security Archives, under the Freedom of Information Act. The author can provide an analysis of the material that advocates torture within this manual on request.

${ }^{20}$ Interview with Kenneth LaPlante, WHINSEC Liaison to the US Army, US DoD, The Pentagon, 3 June, 2004.

${ }^{21}$ Ibid.

${ }^{22}$ US Inspector General, Report of the US Inspector General: Policy and Oversight, Washington DC: Office of the US Inspector General, 1997, pp.7-8.
} 
mental well-being of persons, in particular murder as well as cruel treatment such as torture, mutilation or any form of corporal punishment; (b) collective punishments; (c) taking of hostages; (d) acts of terrorism; (e) outrages upon personal dignity, in particular humiliating and degrading treatment, rape, enforced prostitution and any form or indecent assault; (f) slavery and the slave trade in all their forms; (g) pillage; (h) threats to commit any or the foregoing acts. ${ }^{23}$

Within the Handling Sources manual, the material which "was or could be interpreted not to be consistent with US policy," violated Article $4 .{ }^{24}$ As well as the passages mentioned in the ASDIO report, numerous others also pose a threat to human rights. ${ }^{25}$ One of the highlighted passages states, "Every countermeasure that concentrates on the activities of the guerrillas, without taking into consideration the secret organization and the great preparation before the violence explodes, is destined to fail. The mere elimination of the guerrillas does not alter in any way the basic organization of the insurgents." ${ }^{26}$ Article 4 is clear that if individuals are not directly involved in hostilities, killing them is prohibited. The terms "guerrilla", "communist", "insurgent" and "enemy" are used interchangeably throughout the manual, and it is clear that the individuals referred to using these terms are political opponents of the government and the counterintelligence personnel.

In addition to the passages highlighted in the ASDIO report, I identified 17 more within Handling Sources alone. These included material that advocated infiltration of all types of legitimate social organisation, including youth groups, trade unions, and political parties; using fear and revenge to recruit counterintelligence agents; and, using criminals as informants. ${ }^{27}$ Some of the most disturbing passages relate to the termination of a counterintelligence employee's contract. ${ }^{28}$ For example:

If the insurrection advances to last phases and the guerrillas dominate certain areas that create borders, there is a series of things that could be done, especially if the main thing is to get rid of bin [sic] and it is not important if he talks with the guerrillas or not. Changing his identification is a way that he could not pass verifications by the guerrilla security elements, sending him in a specially dangerous mission for which he has been inadequately prepared, or pass information to guerrilla security elements are methods that could be used. $^{29}$

This is betrayal and poses a direct threat of violence or death. This violates Article 4. A further passage advocates executions:

\footnotetext{
${ }^{23}$ ICRC, 'Protocol Additional to the Geneva Conventions of 12 August 1949, and relating to the Protection of Victims of non-International Armed Conflicts (Protocol II)', International Committee of the Red Cross, 1977, <http://www.icrc.org/ihl.nsf/52d68d14de6160e0c12563da005fdb1b/d67c3971bcff1c10c125641e0052b545?Ope nDocument> Article 4.

${ }^{24}$ US Office of the Assistant Secretary of Defence. Fact Sheet Concerning Training Manuals Containing Materials Inconsistent With United States Policy.

${ }^{25}$ There is some confusion about the compilation and translation of the training manuals. SOAW claim that the training manuals were originally published in English by the US Army, and were then translated into Spanish. They claim that the DoD say that the original English versions have been lost, and therefore no longer exist. The manuals available on the SOAW website are the English translations (by the Army) of the Spanish versions. However, the Office of the Assistant Secretary of Defence claims that the manuals were published in Spanish only, and that no English translations were prepared when they were first compiled. Thus, whereas SOAW states that the DoD claim that the English originals no longer exist, the DoD claims that English originals never existed, and that they were only compiled in Spanish. As regards the English translations that are available from the SOAW website, which SOAW claims are translations by the US Army of the Spanish versions, they are, at times, poorly translated.

${ }^{26}$ US Department of Defence, Handling Sources, Washington DC: US Department of Defence, 1989, School of the Americas Training Manual, <http://www.soaw.org>

${ }^{27}$ Handling Sources, pp. 1-37 and p.128.

${ }^{28}$ Handling Sources, p.130.

${ }^{29}$ Handling Sources, p.130.
} 
The counterintelligence agent could increase the employee's value destroying the structure of the guerrilla organization around said employee. This could be done by means of arrests, executions, or pacification taking care not to expose the employee as the information source. If the employee is one of the few survivors, he could be a key member in a new or different guerrilla organization. Also the employee's reputation could be strengthened in this occasion by means of story fabrication, documents and witnesses, who are not only credible but also difficult to refute, since there will be very few guerrillas that have survived. ${ }^{30}$

Following arrest, individuals cease to be engaged in hostilities, and killing them is a violation of Article 4. A further passage advocates terror and violence against employees no longer needed for intelligence gathering:

In this carefully planned and controlled operation, the agent must discover what actions are needed to strengthen the employee's pretention [sic] an ideal guerrilla recruit [sic]. A vital part of this program is the educational system tending to indoctrinate and recompense government employees who inform when a guerrilla element approaches them and tries to recruit them. The counterintelligence agent could cause the arrest or detention of the employee's parents, imprison the employee or give him a beating as part of the placement plan of said employee in the guerrilla organization. ${ }^{31}$

Under Article 4, non-combatants should not be subjected to violence or to mental intimidation. The calculated use of repression as advocated in this and other manuals in the context of military impunity, which was widespread under military governments in Latin America, is indicative of US complicity in repression. ${ }^{32}$ It was not simply the case that a handful of passages "were not or could be interpreted not to be consistent with US policy", as the DoD stated, but that these manuals are littered with passages which advocate gross human rights violations. They were consistent with CIA material that also advocated torture and assassination. It was the release of these manuals that ignited a campaign against SOA, and culminated in its re-launch in 2001.

\section{WHINSEC - showcase of good practice}

In the late 1990s SOA training shifted from emphasising CI operations to prioritising appropriate civil-military relations and respect for human rights. The changes in the training are genuine and WHINSEC now has a robust human rights programme. These changes coincided with a shift in US foreign policy strategy in the South following the end of the Cold War, away from being characterised primarily by support for repression. Since the end of the Cold War, US foreign policy strategy has been broadly characterised by the promotion of what is referred to as "democracy". Critics variously refer to this as "liberal democracy", including the neo-liberal form which comprises the minimal tax state with minimal social welfare; "market democracy,"36 "low-intensity democracy,"37 and "polyarchy." This is because they question the degree to which this form of democracy invites opting for alternatives that stray far from the systems and practices advocated by the capitalist elite, arguing that US democracy promotion tends to benefit multiple elite groups

\footnotetext{
${ }^{30}$ Handling Sources.

${ }^{31}$ Handling Sources.

${ }^{32}$ The other manuals also contain similar passages and additional passages not mentioned in the ASDIO report which also advocate human rights violations

${ }^{36}$ N Chomsky, 'Market Democracy in a Neoliberal Order: Doctrines and Reality', University of Cape Town, 1997, <http://www.bigeye.com/chomsky.htm>

${ }^{37}$ B Gills; J Rocamora; and R Wilson, (eds.) Low Intensity Democracy: Political Power in the New World Order, London: Pluto, 1993, pp.3-34.

${ }^{38}$ W Robinson, Promoting Polyarchy: Globalisation, US Intervention, and Hegemony, Cambridge: Cambridge University Press, 1996, see chapter one.
} 
both within those states and transnationally, sometimes at the expense of the material needs and human rights of the poor. Whilst not the subject of this paper, the question of whether US training of military forces from the South is part of the process of liberal democracy promotion, or whether it serves more coercive purposes, is worthy of further research.

Changes at SOA came about largely as a result of pressure from SOAW, bolstered by the release of the Spanish language manuals. For the last few years SOAW has attracted 10,000 people to its annual protest at the gates of Fort Benning. ${ }^{39}$ The movement began in 1990, when Roy Bourgeois and nine others held a fast in protest against SOA. ${ }^{40}$ They learned that Salvadoran soldiers implicated in the massacre of all the inhabitants of El Mozote, El Salvador on 10 December 1981, had been trained at SOA. ${ }^{41}$ The official line from the DoD has always been that the re-launch had little to do with claims that it had been complicit in repression, and more to do with new approaches for the post-Cold War world. Army Secretary, Louis Caldera stated:

It's not going to be oriented toward the Cold War challenges of the past [...] It will be oriented toward the security challenges of the future $[\ldots]$ strengthening democracy, fighting drug trafficking, responding to natural disasters, building regional security and cooperation. ${ }^{42}$

Yet various DoD officials attributed the transition to SOAW. Joseph Leuer, Assistant Dean of Academics at WHINSEC, stated:

[SOAW] have done a lot and they don't realise it. They have made this institute the US DoD's best human rights and International Humanitarian Law training institution. They have allowed SOA and now WHINSEC to place into the military lexicon human rights in a positive light. They took a $\$ 4$ million institution and made it the agenda at the national level. Father Roy Bourgeois is the father of WHINSEC. ${ }^{43}$

SOAW forced the ASDIO investigation which set in motion SOA's re-launch. But SOAW are unprepared to concede that the changes are significant.

WHINSEC is now transparent and subject to external oversight. Over a two-month period, I was permitted open access, allowed to speak with any member of staff or student, and could sit in on any training session without prior arrangement. Under Public Law 106-398, a Board of Visitors was established and has to be composed of various individuals from the Committee on Armed Services of both the Senate and House of Representatives; six people designated by the Secretary of Defence, including academics and religious and human rights groups' representatives; one person designated by the Secretary of State; the senior military officer responsible for training and doctrine for the Army; and the commander of SOUTHCOM. ${ }^{44}$ Under the law, the Board is required to meet annually to "Inquire into the curriculum, instruction, physical equipment, fiscal affairs, and academic methods of the

\footnotetext{
${ }^{39}$ Interviewees from the DoD, WHINSEC, and SOA Watch all agreed on the figure of 10,000 protestors.

${ }^{40}$ Interview with Roy Bourgeois at his office, situated outside the gates of Fort Benning, Columbus, Georgia, 20 July 2004.

${ }^{41}$ UNSC, 'From Madness to Hope: the 12-year War in El Salvador: Report of the Commission on the Truth for El Salvador', United Nations Security Council, 1993,

<http://www.usip.org/library/tc/doc/reports/el_salvador/tc_es_03151993_V.html>

${ }^{42}$ K Burger, 'Army Secretary, DoD Back 'Serious Reform' at the School of the Americas', US Department of

Defence - Inside the Army, 2000, <http://carlisle-www.army.mil/usamhi/usarsa/main.htm>

${ }^{43}$ Interview with Joseph Leuer, Assistant Dean of Academics, WHINSEC, 16 August 2004.

${ }^{44}$ US Department of Defence. Floyd D. Spence National Defence Authorisation Act for Fiscal Year 2001. 10

USC 2166. Public Law 106-398.
} 
Institute, [and] other matters relating to the Institute that the Board decides to consider." ${ }^{, 45}$ The Board has elected to meet twice per year. ${ }^{46}$

WHINSEC also now has the most highly developed human rights programme of all US military training. WHINSEC's Charter requires that all courses, which last 12 weeks, provide a minimum of eight hours mandatory instruction on human rights, the rule of law, due process, civilian control of the military, and the role of the military in democratic society. ${ }^{49}$ WHINSEC is the only US military institution where human rights instruction is incorporated into every course. ${ }^{50}$ This minimum is not only adhered to, but exceeded. WHINSEC students actually receive more than this, because the democracy part is taught separately. They therefore get a minimum of 11 hours. ${ }^{51}$ The Board of Visitors has played an important role in developing the human rights programme. Much of the human rights training I observed was of a high standard.

Despite this, SOAW continue to focus on WHINSEC. Discussions with various SOAW staff members revealed that even they do not believe that WHINSEC poses any immediate threat to human rights. I asked Roy Bourgeois if he believes WHINSEC is promoting torture. He replied:

No, not torture 101. But just bringing those soldiers to US institutions for combat training, that to me is a contradiction to what people in Latin America need. I have no doubt that the teaching in the past did involve torture. But our scrutiny now forces the Pentagon to put the school under the microscope. Before they could get away with it. Now they can't. ${ }^{52}$

Yet SOAW continue to make the claim that WHINSEC teaches torture. In a campaigning video posted on the SOAW website in April 2006, consisting of a spoof recruiting tool for WHINSEC, the voice-over states:

At the School of the Americas, Western Hemisphere Institute for Security Cooperation, we're serious about success $[\ldots .$.$] The curriculum for this$ upcoming semester includes: Bleeding Edge Torture Schemes, Streamlined Sniper Training, Interrogation Tactic Focus Groups. ${ }^{53}$

This is simply untrue. As discussed above, there is no evidence that there is any training which advocates the use of torture at WHINSEC, and even the SOAW leadership admit this. There are no "sniper" courses on offer either, nor indeed any courses specifically oriented towards use of weapons, although all military WHINSEC staff, as with all members of the US armed forces, do have to keep their own weapons maintenance and weapons use training up to date. Neither are there any courses on interrogation or psychological operations on offer, neither have there been since the School was relaunched. The animation also contains a fabricated "quotation", which it is claimed are the words of General Vazquez Velasco, former head of the Venezuelan Army:

\footnotetext{
${ }^{45}$ Ibid.

${ }^{46}$ The minutes from these meetings are documented and available at:

<http://www.fido.gov/facadatabase/AgenciesList.asp>

${ }^{49}$ US Department of Defence, 'Directive Number 5111.12. Subject: Western Hemisphere Institute for Security Cooperation', US Department of Defence, 2002,

<http://www.benning.army.mil/whinsec/uploadedFiles/InstituteCharter.pdf>

${ }^{50} \mathrm{~J}$ Cope, 'International Military Education and Training: An Assessment', Institute for National Strategic

Studies, 1995, <http://www.ndu.edu/inss/macnair/mcnair44/m44cont.html>

${ }^{51}$ Interview with Major Tony Raimondo, Judge Advocate and Chief of Human Rights Training, WHINSEC, 9

August 2004. The breakdown and explanation of the human rights and democracy training was also given at the WHINSEC Board Meeting on 16 July 2004.

${ }^{52}$ Interview with Father Roy Bourgeois at his office, situated outside the gates of Fort Benning, Columbus, Georgia, 20 July 2004.

${ }^{53}$ School of Americas Watch, Shut Down the SOA Flash Movie (Washington DC: School of Americas Watch, 2006), <http://www.soaw.org/new/flash.php>
} 
My time at the School of the Americas laid the groundwork for my attempt to overthrow the democratically elected government of Venezuela in 2002.

Maybe one day I can join the ranks of many of my SOA peers and become military dictator, $[$ cough $]$ president of my own country. ${ }^{54}$

General Vazquez Velasco did attend the School of the Americas in 1988 at which time he was a Lieutenant Colonel. He took the Command and General Staff Officers Course. He was also one of the military leaders involved in the coup to overthrow Hugo Chavez in 2002, although he claimed that it "was not a coup nor insubordination, but a position of solidarity with all the Venezuelan people." $"$ There is no record of him ever having made a statement linking his involvement with the coup and the training he received at SOA.

In addition, reference is made in the video to research undertaken by Kate McCoy. The video states, "Research done at the University of Wisconsin shows that the more SOA classes a soldier takes, the more likely he is to commit human rights abuses."56 McCoy's findings, however, are demonstrably false due to a flawed methodology. She undertook a statistical analysis of data relating to graduates over a forty year period. ${ }^{57}$ She constructed a sample of 11,797 graduates which includes students from six countries (Argentina, Brazil, Peru, Guatemala, El Salvador and Panama) who attended SOA between 1960 and $2000 .^{58}$ The dataset draws on student records of graduates from its inception until 2000, which were released by the US government under the Freedom of Information Act (FOIA), following pressure from SOAW. ${ }^{59}$ The dataset also draws on a SOAW database entitled "Notorious Graduates", which is compiled from information from various non-governmental organisations focusing on human rights, media, and UN Truth Commissions, and indicates whether any allegations have been made which link individuals listed in the records released under the FOIA to acts of repression. ${ }^{60}$ McCoy refers to such cases as those in which students or instructors were "caught for human rights violations." ${ }^{\text {"1 }}$ McCoy does not define what she means by "caught", and she fails to note that she is actually referring to cases in which allegations of repression were made, nearly all of which have not been proven. These amount to 153 cases in total. So of the 11,797 graduates within her dataset, there are allegations against 153 of them, which amounts to 1.3 per cent of the total number of graduates included within her dataset. The records collated by SOAW reveal that 9 of the 153 graduates that McCoy states have been "caught" for human rights abuses have actually been convicted. ${ }^{62}$ Of these 9 , three were sentenced by Peruvian military courts, and three were sentenced by civil courts in Argentina, El Salvador and Panama. One Guatemalan was sentenced by a US court, and it is not clear what type of court sentenced the other two, who were from Peru. ${ }^{63}$ Thus, of those against whom allegations have been made, there is a conviction rate of 6 per cent. This amounts to convictions against just 9 out of 11,797 graduates of the School, or 0.08 per cent of all graduates. The remaining 144 graduates against whom allegations have been made have not been found guilty of any crime. Neither is there any evidence within the SOAW dataset to indicate whether legal proceedings have been brought against any of the remaining 144 graduates allegedly involved in repression. McCoy fails to point this out. Of course it is possible that some of the allegations made were false, a further point that McCoy fails to make. Thus, her dataset is further invalidated because some of the cases she refers to may be false.

\footnotetext{
${ }^{54}$ Ibid.

${ }^{55}$ Barry Cannon, 'Venezuela, April 2002: Coup or Popular Rebellion? The Myth of a United Venezuela', Bulletin of Latin American Research, vol.23, no. 3 (2004), pp.285-302.

${ }^{56}$ School of Americas Watch, Shut Down the SOA Flash Movie.

${ }^{57}$ McCoy, 'Trained to Torture', pp.4-5.

${ }^{58}$ Ibid. pp.50-51.

${ }^{59}$ Sean Donahue, 'General Clark, the School of the Americas and US Values', School of Americas Watch, 2004, <http://www.soaw.org/new/article.php?id=721>

${ }^{60} \mathrm{McC}$ cy, 'Trained to Torture', pp.47-48. SOAW, 'Notorious Graduates (By Country)', School of Americas

Watch, 2004, <http://www.soaw.org>

${ }^{61}$ McCoy, 'Trained to Torture', pp.47-48.

${ }^{62}$ SOAW, 'Notorious Graduates (By Country)'.

${ }^{63}$ Ibid.
} 
The incidence of acts of repression committed was probably far higher than McCoy's research suggests, given the context of impunity. Had she acknowledged that her findings were based on allegations of repression, rather than proven, she might have been able to make her case against SOA more effectively. In a climate of extreme political violence and impunity, people are unlikely to report repression out of fear of reprisals. McCoy's findings may only be the tip of the iceberg.

In interviews with SOAW staff I pointed out the flawed methodology of McCoy's research, which they acknowledged. Jacqueline Baker, then SOAW legislative coordinator stated that "it is not our strongest lobbying tool", and Eric LeCompte said, "I agree with your assessment." ${ }^{64}$ Roy Bourgeois went further, stating:

I've never mentioned it or used it in my talks. It is important for the School to look at it. We have to be honest and accurate. I don't give it much importance myself. I don't believe others have used it either. It is not significant. ${ }^{65}$

Given these acknowledgements of the flaws of McCoy's research, it should not have been included in the video.

Many SOAW members continue to believe that WHINSEC is no different from SOA, and that it continues to pose a threat to human rights, despite the acknowledgement among SOAW's leadership that this is not the case. The inclusion of misinformation in SOAW's campaigning tools, such as the flash animation, help to explain these assumptions among the SOAW membership. As a consequence, and conveniently for the Department of Defence, attention remains focused on WHINSEC, diverting attention from the majority of US military training, which remains secretive and devoid of adequate human rights training. The change in focus at WHINSEC to the promotion of appropriate civil-military relations seems to be a positive step forward, in that it rejects the notion that the military should play any role in governing the country, and should, instead be subordinate to civilian leaders. Courses such as Resource Management and Democratic Sustainment do focus on ensuring that military forces are accountable, and this is a necessary and important part of ensuring that military forces are at the service of civilian governments.

Nevertheless, counter-drug operations is an area which could be undertaken by a variety of civilian institutions including the police, rather than the military. How then can training of military forces in such areas be justified, when these roles could be fulfilled by civilian institutions? I suggest that using the military to perform such roles is not necessarily the mark of progressive democracy, and can impede progress in the area of human rights. I also asked Bourgeois why the focus of SOAW is still WHINSEC. He replied:

This movement is not so much about the school but about US foreign policy. But as activists we know what will mobilise people. We have to maintain our focus. If we said we are a moving out of the SOA issue and onto the bigger issue we would be losing our flagship with so much history. ${ }^{66}$

This view was shared by other staff from the SOAW office in Washington DC including Eric LeCompte:

Our efforts on foreign policy need to be much bigger. It is not our intention to stop with one school. The existence of the school does give us time to build a

\footnotetext{
${ }^{64}$ Interviews with Jacqueline Baker, SOAW Legislative Coordinator, SOAW office, Washington DC, 7 June 2004 and with Eric LeCompte, Events and Outreach Coordinator, SOAW Office, Washington DC, 16 June 2004.

${ }^{65}$ Interview with Father Roy Bourgeois at his office, situated outside the gates of Fort Benning, Columbus, Georgia, 20 July 2004.

${ }^{66}$ Interview with Father Roy Bourgeois at his office, situated outside the gates of Fort Benning, Columbus, Georgia, 20 July 2004.
} 
movement, but it needs to be a movement with broader connections to foreign policy. I believe we will close the school but I hope it won't be too soon so that we can build a movement to make the connections with foreign policy. ${ }^{67}$

Thus the strategy is that if wider questions of US foreign policy are to be raised, the movement needs to retain momentum directed specifically at WHINSEC, because of the symbolic power of its murky past.

A further strategy of the SOAW leadership has been to meet with senior government and military officials from Latin American states and to try to persuade them to stop sending their personnel to WHINSEC. SOAW report that they have successfully persuaded the Venezuelan, Argentina and Uruguay governments to cease sending nationals from those states to WHINSEC, following meetings between SOAW delegations and senior officials from the governments of those states in 2004, in the case of Venezuela, and 2006 in the cases of Uruguay and Argentina. ${ }^{68}$ Missing from SOAW's accounts of these processes is the fact that, because of the refusal by the governments of Venezuela and Uruguay to sign an Article 98 agreement with the US, agreeing not to seek prosecution of US citizens in the International Criminal Court, all IMET, FMF, Excess Defence Articles, and non-drug Emergency Drawdown Authority Funds have been withdrawn from those states. ${ }^{69}$ That means that those states cannot send their personnel to WHINSEC under the IMET and FMF programmes, and could only receive training at WHINSEC if they funded it out of their own budgets. The Uruguayan and Venezuelan governments have taken a stand against the US over the issue of freedom from prosecution at the International Criminal Court of US citizens, and for this reason are no longer eligible to receive training at WHINSEC funded by the US. Whether or not they would have withdrawn their personnel from receiving WHINSEC training if this were not the case is not clear. In the case of Argentina, there had already been a decline in the numbers of students that were being sent to WHINSEC before SOAW met with the Argentine Defence Minister, Nilda Garré. Five to six sergeants were due to attend WHINSEC for the NCO Professional Development Course, in session in April 2006, but only one of them attended. ${ }^{70}$ SOAW nevertheless report that Garré agreed this would be the last individual that Argentina would send to WHINSEC. $^{71}$ These withdrawals of Latin American forces from WHINSEC cannot simply be attributed to the efforts of SOAW. They are a symptom of wider resistance on the part of Latin American military and political leaders to US policies. ${ }^{72}$ The policy of withdrawing IMET and FMF training as a punishment against those states who refuse to sign Article 98 agreements is deeply unpopular within the Department of Defence, and General John Craddock, Commander of SOUTHCOM recently testified before the Senate Armed Services Committee that this action was opening up opportunities for China to provide training to the military forces of those states whose IMET and FMF training has been withdrawn. Indeed China is already providing some non-lethal military training in Spanish to those states. ${ }^{73}$

\footnotetext{
${ }^{67}$ Interview with Eric LeCompte, Staff member, SOAW, SOAW Office, Washington DC, 16 July 2004.

${ }^{68}$ School of Americas Watch, 'Argentina and Uruguay Abandon SOA! Critical Victory for Human Rights Organisations Across the Americas', SOA Watch, 28 March 2006,

<http://www.soaw.org/new/article.php?id=1290>; School of Americas Watch E-mail / Website news item,

'Venezuela Ceases All Training of Venezuelan Troops at the School of the Americas (SOA/WHINSEC)',

School of Americas Watch, 2004, <http://www.soaw.org/news/docs/venezuela.doc>

${ }^{69}$ Centre for International Policy, '"Article 98" Agreements and the International Criminal Court', Latin

America Working Group and Centre for International Policy: Just the Facts: A Civilian's Guide to US Defence and Security Assistance to Latin America and the Caribbean, 4 April 2005,

<http://ciponline.org/facts/art98.htm>

${ }^{70}$ Personal correspondence with Lee Rials, WHINSEC Public Affairs Officer, 13 April 2006.

${ }^{71}$ School of Americas Watch, 'Argentina and Uruguay Abandon SOA'.

72 See also Greg Grandin, 'The Wide War - How Donald Rumsfeld Discovered the Wild West in Latin

America', Tomdispatch.com, 7 May 2006, <http://www.truthout.org/docs_2006/printer_050806L.shtml>

${ }^{73}$ Personal correspondence with Lee Rials, WHINSEC Public Affairs Officer, 13 April 2006.
} 
Focusing on WHINSEC is not the best use of resources, given the positive nature of its training and the urgent need for greater scrutiny of training beyond WHINSEC, which, as I will show, is far-reaching but highly secretive. The movement could begin targeting other training providers, such as Fort Bragg, where Special Operations forces are trained, or Fort Huachuca, where intelligence training is formulated. Rather than close WHINSEC, as SOAW advocate, pressure should be put on the Department of Defence to ensure that at the very least, all other US military training initiatives should be subject to the same level of external oversight as WHINSEC, and that all those in receipt of US military training, whether US nationals or foreigners, should receive the same levels of human rights and democracy training as WHINSEC students do. This is not to say that the question of whether the human rights training provided is effective should be abandoned. Indeed, greater pressure needs to be exerted upon the Department of Defence to reveal precisely how they can be so sure that this training is effective, and especially bearing in mind the Haditha massacre in Iraq.

\section{Training beyond WHINSEC}

WHINSEC training has become a model of best practice but is undermined in five ways. Firstly, the majority of the training beyond WHINSEC remains unaccountable, and is not subject to the same requirements to provide human rights training as WHINSEC. WHINSEC represents just one percent of all US training of foreign military forces. Currently no other US training institution is subject to the same rules as WHINSEC with regard to mandatory human rights training. All individuals, domestic or foreign, in receipt of US military training, receive training on the Laws of Armed Conflict (LOAC). The primary document relating to this is Army Field Manual 27-10, The Law of Land Warfare. $^{74}$ US Army personnel at WHINSEC regularly commented that their own experience of standard US training on the LOAC was very basic compared with WHINSEC's human rights training. This was confirmed by a representative from the International Committee of the Red Cross (ICRC). He was delivering three days of training at WHINSEC on International Humanitarian Law. He indicated that he visits a number of US training institutions, both for US nationals and foreign forces, but he is not given the three-day slot that he gets at WHINSEC. He simply has to explain what the ICRC's remit is, as part of the LOAC training. I observed his sessions and found them to be some of the best in terms of challenging the students to really think through their responsibilities under international law. The students had to grapple with difficult combat simulations, and the message was reiterated time and again that they must do everything possible to resist illegal orders. ${ }^{75}$ The ICRC representative said he has come across a "pick and choose" attitude among US military personnel where human rights training is concerned. ${ }^{76}$ Whilst the DoD invites an ICRC representative to deliver human rights training at WHINSEC, and limited LOAC training at other US military training institutions, it chose to ignore the ICRC's investigation into treatment of detainees at Guantanomo Bay and Abu Ghraib, and other detention facilities, until Pentagon memorandums on ICRC visits to Guantanomo were leaked to the Washington Post, which raises the question of how seriously the US administration and DoD take the ICRC in the current climate. ${ }^{77}$

The second way in which WHINSEC's efforts are undermined relates to the provision of training to military personnel from countries with appalling human rights records. The Leahy Law, implemented in 1996, was intended to prevent individuals with poor human rights records from receiving training under the counter-narcotics programme. It was extended to all forms of State Department training, and then in 1999, to training provided

\footnotetext{
${ }^{74}$ US Department of Defence, 'Field Manual 27-10. The Law of Land Warfare', US Department of Defence, 1956, <http://www.globalsecurity.org/military/library/policy/army/fm/27-10/index.html>

${ }^{75}$ Observations of Command and General Staff Officers Course sessions, WHINSEC, 20-22 July 2004.

${ }^{76}$ Interview with International Committee of the Red Cross representative, WHINSEC, 21 July 2004.

${ }^{77}$ S Hersh, Chain of Command. The Road from 9/11 to Abu Ghraib, London: Penguin Books, 2004, p.13.
} 
by the Department of Defence. ${ }^{78}$ Throughout this period, however, under the auspices of the Joint Combined Exchange Training (JCET) programme, the US was able to continue to provide training to personnel from countries that were banned from receiving training on human rights grounds. Masquerading as training programmes for the US' own Special Forces, JCET was used to provide training for countries that were banned from receiving training because of their poor human rights records. Dana Priest found that under JCET, US Special Forces trained foreign troops from countries such as Indonesia, Colombia and Pakistan, which Congress had blacklisted. ${ }^{79}$ Congress cut off all IMET funding to Indonesia in 1991 when it was discovered that Indonesian troops supplied with US weapons had massacred at least 280 unarmed people in Dili, East Timor. Some Expanded IMET (E-IMET) programmes were offered in 1995. The E-IMET programme was developed by Congress for countries that were banned from receiving IMET, and included training in civil-military relations, military justice, resource management and human rights, but with no combat training. ${ }^{80}$ However, between 1991 and 1998 US Special Forces conducted 41 training exercises with Indonesian troops, including with 26 individuals from Kopassus, Indonesia's own Special Operations unit, which US and Australian defence officials knew to be behind killings and torture in East Timor and Irian Jaya. US officials stated that the training involved Counterterrorism, mission planning, sniper skills, closequarters urban warfare, crowd control, and rapid infiltration of troops. The East Timor Action Network found that the training had also included psychological operations. ${ }^{81}$ The Department of Defence insisted that discussions of international human rights standards had also been included in the training. ${ }^{82}$ The effectiveness of whatever efforts were made to instil notions of respect for human rights and civilian control of the military during the JCET operations in Indonesia, was called into question by the remarks of Colonel Charles McFetridge, defence attaché at the US embassy in Jakarta, to Priest. He told Priest that when he began to "push the issue of civilian control of the military, the Indonesians became incredulous. They would look at me and say, 'We're not training civilians to be generals." 83 The message was clearly not getting through.

Since the advent of the "War on Terror" IMET training has been re-introduced to countries that were previously banned from receiving training by Congress, Indonesia among them. Lumpe notes that by March 2002 Bush had identified nineteen countries in Asia, Africa, the Middle East, Central Asia and Latin America as allies in the "War on Terror". Yet, she adds, the security forces in fourteen of these countries had been cited by the State Department for committing serious human rights abuses. ${ }^{84}$ Indonesia was a case in point. Mary Robinson, who was the United Nations High Commissioner for Human Rights visited East Timor in 1999 reported that even during the 1990s:

There was overwhelming evidence that there had been a deliberate, vicious and systematic campaign of gross violations of human rights in East Timor, including mass killings, forcible expulsions, violence against women and a breakdown of law and order. The extreme violence ... was initiated by different militia groups, in which elements of security forces were also involved. ${ }^{85}$

\footnotetext{
${ }^{78}$ Lumpe, p.30.

${ }^{79}$ Dana Priest, The Mission. Waging War and Keeping Peace with America's Military, (New York: W.W. Norton and Company, 2004), p.222.

${ }^{80}$ L Lumpe, US Foreign Military Training: Global Reach, Global Power, and Oversight Issues (New Mexico: Foreign Policy in Focus, 2002), p.27.

${ }^{81}$ Lumpe, p.19.

${ }^{82}$ Priest, The Mission, pp.219-222.

${ }^{83}$ Ibid. p.219 and 223.

${ }^{84}$ Lumpe, p.5.

${ }^{85}$ United Nations. Press Release Hr/CN/975. Commission of Human Rights Opens Special Session on East

Timor. (New York: United Nations Organisation, 24 September 1999), <http://www.un.org/index.html>
} 
This demonstrates that the legislation in place is wholly insufficient. Even the limited laws that are in place are now being ignored in the name of the "War on Terror". The military ban on training to Indonesia was retained by Congress under the Foreign Operations Appropriations Act, but a last minute addition to the 2002 Defence Department Appropriations Act included \$17.9 million to establish a Regional Defence and CounterTerrorism Fellowship Programme. ${ }^{86}$ Indonesia received $\$ 600,000$ worth of IMET training in $20044^{87}$ If the US administration were genuinely committed to ensuring that foreign military training assists in improving human rights, the loopholes that enable the laws to be circumvented would be closed; training would not be offered to countries with poor human rights records, and US Special Forces would not be assisting military forces implicated in human rights abuses to develop close-quarters urban warfare and psychological operations.

The third way in which WHINSEC's progress is undermined has to do with the US military's Rules of Engagement and Standing Rules of Engagement. They are predicated on the principle of pre-emption, which may result in violations of the LOAC. The preemption principle is discussed by Juan Cole and an anonymous contributor to his web $\log .{ }^{88}$ The Rules of Engagement and the Standing Rules of Engagement are subsumed by the LOAC, and cannot authorise anything that would be prohibited under the LOAC. ${ }^{89}$ Nevertheless, the principle of pre-emption enables military personnel to protect themselves from anything they perceive to be hostile intent. Cole's correspondent argues that as a result, there is great potential for the "liberal use of force", which may result in human rights violations. ${ }^{90}$ Therefore, even if WHINSEC's human rights training were to be emulated across the US military, it is possible that the LOAC might be violated when individuals take pre-emptive actions, as is permitted under the Rules of Engagement and the Standing Rules of Engagement, when they perceive the acts of others in conflict zones to be hostile, even if they may not be.

The fourth way in which WHINSEC is undermined is that whilst its human rights training was of a very high standard, some discussions indicated that attitudes towards human rights are not positive, even among WHINSEC staff. During one session which focused on civilmilitary relations in Colombia, the only mention of human rights organisations was in the context of a case study, which formed a formal part of the course's curriculum, where the students were encouraged to imagine they were part of a committee dealing with human rights organisations making false accusations against the armed forces. ${ }^{91}$ Throughout the session this was the only mention of human rights organisations, and they were being cast in an extremely negative light. This is subtle, but to phrase the scenario in terms of "false allegations" rather than simply "allegations", sends signals to the students about what they can expect of human rights organisations.

Finally, there is a complacent attitude among DoD personnel about the need for human rights training among US forces. I asked DoD representatives why the US' own forces are not provided with the same levels of human rights training as WHINSEC students. One representative commented:

\footnotetext{
${ }^{86}$ Lumpe, p.19.

${ }^{87}$ US Department of State. FY2004: Congressional Budget Justification for Foreign Operations - Military Assistance, p.154.

${ }^{88} \mathrm{~J}$ Cole, 'US Military Rules of Engagement and the Iraq War', Informed Comment: Thoughts on the Middle East, History and Religion, Weblog of Juan Cole, 2005, <http://www.juancole.com/2005/08/us-military-rulesof-engagement-and.html>

${ }^{89}$ The military doctrine that deals with this issue is DoD, 'Operational Law Handbook, Chapter 5: Rules of Engagement', US Department of Defence, Judge Advocate General's Legal Centre and School, 2003, <http://www.juancole.com/2005/08/us-military-rules-of-engagement-and.html>

${ }^{90} \mathrm{~J}$ Cole, 'US Military Rules of Engagement and the Iraq War'.

${ }^{91}$ Democratic Sustainment Course, Case Study on Colombian Civil-Military Relations, WHINSEC, Class observed on 29 July 2004.
} 
American Army personnel don't need to go into the same depth of human rights and democracy training because US personnel have a pre-existing cultural understanding of this before they get anywhere near training. ${ }^{92}$

This was a typical attitude among Pentagon and WHINSEC staff. When such attitudes prevail, it is not surprising that US military personnel are assumed to be mostly beyond committing human rights violations. It is also unclear whether the human rights training at WHINSEC is effective, and no one within the DoD or at WHINSEC was able to provide a persuasive answer to this question. Just because all the legal requirements concerning mandatory human rights training are met, does not mean that it is effective in preventing repression. Neither does it mean that the administration is committed to preventing repression.

\section{Condoning repression since 9/11}

Since the advent of the "War on Terror" training has been offered to countries that were previously banned by Congress because of their poor human rights records. Laura Lumpe notes that by March 2002 Bush had identified 19 countries in Asia, Africa, the Middle East, Central Asia and Latin America as allies in the "War on Terror". Yet, she adds, the security forces in 14 of these countries had been cited by the Department of State for committing serious human rights abuses. ${ }^{93}$ This makes a mockery of attempts to establish credible human rights training at WHINSEC. This has coincided with a resurgence of support for repression in US foreign policy strategy since 9/11, which sits alongside US democracy promotion efforts.

Figures within the current US administration have been involved in attempts to redefine torture. Jay Bybee, head of the Justice Department's Office of Legal Counsel, wrote a memorandum for the attention of the President's Counsel in early August 2002, advising on what constitutes torture:

We conclude that for an act to constitute torture [...] it must inflict pain that is difficult to endure. Physical pain amounting to torture must be equivalent in intensity to the pain accompanying serious physical injury, such as organ failure, impairment of bodily function, or even death. For purely mental pain or suffering to amount to torture under Section 2340 it must result in significant psychological harm of significant duration, e.g. lasting for months or even years. ${ }^{94}$

He concludes that whilst sensory deprivation techniques "may amount to cruel, inhuman or degrading treatment, they do not produce pain or suffering of the necessary intensity to meet the definition of torture." 95 The memorandum continues, "From these decisions, we conclude that there is a wide range of such techniques that will not rise to the level of torture. ${ }^{.96}$ The implication is that such techniques may be admissible. ${ }^{97}$ President Bush had previously insisted in a secret statement that members of the Taliban and Al Qa'ida be treated humanely. ${ }^{98}$ Despite Bush's call for humane treatment, in interviews with DoD

\footnotetext{
${ }^{92}$ Interview with Kenneth LaPlante, WHINSEC Liaison to the US Army, US DoD, The Pentagon, 24 June, 2004.

${ }^{93}$ L Lumpe, 'US Foreign Military Training: Global Reach, Global Power, and Oversight Issues', Foreign Policy in Focus, 2002, <http://www.fpif.org/papers/SRmiltrain.pdf>

${ }^{94} \mathrm{~J}$ Bybee, 'Memorandum for Alberto R Gonzales, Counsel to the President. Re: Standards of Conduct for Interrogation under 18 USC 2340-2340A', US Department of Justice, Office of Legal Counsel, 1 August 2002, in K Greenberg and J Dratel, (eds.), The Torture Papers. The Road to Abu Ghraib, Cambridge: Cambridge University Press, 2002, pp.172-214.

${ }^{95}$ Ibid. p.2.

${ }^{96}$ Ibid.

${ }^{97}$ Hersh, Chain of Command, p.5.

${ }^{98}$ President G Bush, 'Order signed by the President on the Treatment of Detainees', Associated Press, 2002, <http://www.kron.com/global/story.asp?s=1962000\&ClientType=Printable>
} 
personnel it was apparent that there was widespread acceptance of the techniques Bybee referred to. I asked Ken LaPlante about the redefinitions of torture, and where he thought the line should be drawn. He stated:

The original intent was to get information. But these things must have been repeated so many times that it became unclear what the redefinitions were. This was an evolutionary process. I draw the line with what the law allows. Abu Ghraib happened because of a leadership failure. The definition of torture allows flexibility. How can you define comfort? In terms of the techniques, some are not wrong, e.g. deprivation of light, rest is uncomfortable. Temporary withholding of food to disorientate an individual and to show them that you are in charge is also fair game. Placing a bag over someone's head, to disorientate them and show them that you are in charge is also acceptable. In my training I had a bag put over my head. Putting a sack on a guy's head is not wrong, up to a point. But would I soak it with water so that they feel like they're suffocating? No, I've had that done in training and it's awful. Not providing food at all is a violation. Taking their clothes off and walking them naked to get new clothes, sure, it could take five hours to take them to get new clothes, that's not wrong. But then you are making a calculated risk doing something like that, particularly if their culture is sensitive to the immodesty of it, but then you are accountable if you decide to take that risk, and you would justify it. Enforced nudity for days on end without intent is also a violation. Sexual contortions and abuse, and photograph-taking are all violations. ${ }^{99}$

LaPlante indicates not only his acceptance of some acts prohibited under Article 4, but also that there was confusion about what precisely constitutes torture, whether the administration had actually redefined torture, and if so, what was permissible.

By April 2003, a working group commissioned to report on detainee interrogations, headed by Donald Rumsfeld, recommended the approval of a whole set of techniques for use in interrogation of "unlawful combatants." Among these were hooding, but only during interrogation; dietary manipulation, but with no intended deprivation of food and water and no adverse medical or cultural effects; environmental manipulation, such as adjustment of temperature or introducing unpleasant smells, but not in a way that would cause injury; sleep adjustment which entails the adjustment of sleeping times, but not sleep deprivation; threat of transfer to a third country that the subject is likely to fear would subject him to torture or death; forced grooming, i.e. forcing a detainee to shave their hair or beard; prolonged standing, but not for more than four hours in a 24 hour period; sleep deprivation, allowing individuals to rest briefly but repeatedly waking them, but not for longer than four days in succession; removal of all clothing, with no time limit placed on this; increasing ${ }_{101}^{a n x i e t y}$ by use of aversions, e.g. the presence of a dog without directly threatening action.

Under Article 4, threats of torture are a form of mental torture and are prohibited. It is only a few small steps from these degrading acts to the torture that occurred at Abu Ghraib. This is of grave concern in light of the widespread confusion that LaPlante alluded to. Also of concern is the recommendation that detainees be threatened with transfer to third party countries where they might be tortured. This was not limited to threats, but has occurred since 2001.

\footnotetext{
${ }^{99}$ Interview with Kenneth LaPlante. WHINSEC Liaison to the US Army, US DoD, The Pentagon, Thursday 3 June, 2004.

${ }^{101}$ D Rumsfeld, Working Group Report on Detainee Interrogations in the Global War on Terrorism: Assessment of Legal, Historical, Policy and Operational Considerations, Washington DC: Office of the Secretary of Defence, 4 April 2003, in KGreenberg and J Dratel, (eds.) The Torture Papers, pp.286-359.
} 
The extent of the programme in which the US transfers terror suspects to third party states that use torture, a policy known as extraordinary rendition, is unknown. Various detainees in the "War on Terror" have indicated that they were flown to third party countries, often Egypt, on a US Gulfstream V jet, were held there and tortured. Alleged victims include Mamdouh Habib, Muhammed Zery and Ahmed Agiza. A handful of extraordinary rendition victims are being represented by human rights lawyers against the US government. ${ }^{105}$ Information from airport officials, 'plane spotters, and public documents indicate that the same jet, with tail number N379P, has been used to transport detainees into or out of Jakarta, Indonesia, Pakistan, Egypt and Sweden. It has also been reported that the CIA is running secret prisons in Eastern Europe to which a number of terror suspects have been flown, and held without trial. ${ }^{107}$ The jet is registered to a private US company, which lists directors and officers who seem only to exist on paper, each of whom have recently been issued Social Security numbers and an address consisting only of a post box. ${ }^{108}$ Civilian aircraft landing records indicate that the jet has permission to use US military airfields worldwide The CIA has refused to comment on the policy and any link it has with this jet. ${ }^{111}$ Meanwhile, following the passing of legislation by the Senate that would outlaw the cruel, inhuman or degrading treatment of anyone held by the US, anonymous officials informed the New York Times and Washington Post that Dick Cheney, vice-president, proposed a change so that the law would not apply to counter-terror operations abroad or to operations conducted by the CIA. ${ }^{12}$

Any efforts to instigate foreign military training that fosters an attitude of respect for human rights, as at WHINSEC, are undermined by attitudes within the administration towards torture and by policies which violate Article 4 . The credibility of US claims to be promoting democracy in the South is called into question in light of these attempts to circumvent human rights law, and in light of the provision of military aid to countries with poor human rights records.

Even at WHINSEC there are signs of a return to less transparent means. At the end of 2004, the White House unexpectedly intervened in the selection of WHINSEC's Board of Visitors, objecting to the reinstatement of all but one of the members, and insisting on the selection of new, White House-approved members. Those sacked included the Board's chair, Steven Schneebaum, a human rights lawyer and outspoken critic of US policy in the "War on Terror", and Deborah Avant, an academic, both of whom were extremely active in ensuring the instigation of credible human rights training at WHINSEC. The only retained Board member was Jose Sorzano, former deputy ambassador to the UN under Jeanne Kirkpatrick, and known for his right wing views. ${ }^{113}$ He is now the chairman of the Board, replacing Steven Schneebaum. The new members include Ben Hand, a republican and 2006 candidate for the Alabama Supreme court, Reverend Cletus Kiley from the US conference of Catholic Bishops, Reverend Robert Morlino, fourth bishop of Madison, Wisconsin, María Domínguez, an immigration lawyer from Miami, and Victor Bonilla,

\footnotetext{
${ }^{105} \mathrm{~J}$ Mayer, 'Outsourcing Torture. The Secret History of America's 'Extraordinary Rendition' Programme', The New Yorker, (New York), 7 February 2005, <http://www.newyorker.com/printables/fact/050214fa_fact6>

${ }^{107}$ D Priest, 'CIA Holds Terror Suspects in Secret Prisons,' The Washington Post, (Washington DC), 2 November 2005, p.A01,<http://www.washingtonpost.com/wp-

dyn/content/article/2005/11/01/AR2005110101644_pf.html>

${ }_{108}$ Mayer, 'Outsourcing Torture', ; Priest, 'CIA Holds Terror Suspects,'

${ }^{111}$ D Priest, 'Jet is an Open Secret in Terror War', Washington Post, (Washington DC), 27 December 2004, <http://www.washingtonpost.com/wp-dyn/articles/A27826-2004Dec26.html>

${ }^{112}$ J Wilson, 'Bush Seeks CIA Exemption from Ban on Cruelty to Terror Suspects', The Guardian, (London), 26 October 2005, p.16.

${ }^{113}$ Personal correspondence with Professor Deborah Avant, 12 December 2005, and with Lee Rials, WHINSEC Public Affairs Officer, 12 December 2005; Interview with Jose Sorzano, Arlington, Virginia, 21 June 2004, in which he excused US complicity in human rights violations during the Cold War in Latin America, arguing, "As you know the Monroe Doctrine declared the Western Hemisphere to be the US' zone of influence. We had an interest in preventing the Soviet Union, but also since urban guerrillas are associated with the Soviet side, we had a propensity to help the other side."
} 
retired senior advisor to the Organisation of American States. ${ }^{114}$ In addition, at the end of 2004, Retired Lieutenant General Gordon Sumner, previously chairman of the InterAmerican Defence Board and Special Assistant to the Secretary of State for Latin American Affairs, and now Consultant with Sumner Associates, was appointed as an advisor to the WHINSEC Board of Visitors. He is also Board member of the International Security Council, which Edward Herman and Gerry O'Sullivan have described as the "main US agency of the Moon system in the field of terrorism propaganda", with its head, Joseph Churba, acknowledging the "generous and unwavering support of Reverend Sun Myung Moon." The proclaimed goal of this organisation is to formulate "global strategic analysis" which includes defending Israel's policy in Palestine. ${ }^{115}$ Sumner is also a member of the Council for National Policy, which brings together political, business and religious leaders to plan the strategy of the religious right in the US. ${ }^{116}$ Deborah Avant rightly expressed concern that in light the White House's intervention and of this shift to the right in the Board of Visitors, WHINSEC may not be able to resist the general trend in US foreign policy towards less transparent and more repressive means. ${ }^{117}$

A further recent development at WHINSEC which is a cause for concern is the diminishing number of Latin American states taking up places on the courses which place a heavy emphasis on democracy and human rights. According to Lee Rials, WHINSEC public affairs officer, two courses have had to be dropped in 2006 until interest picks up again. These are the Democratic Sustainment course and the International Operational Law course. ${ }^{118}$ It has not been possible to ascertain why this is. It may simply be attributable to the withdrawal of troops from WHINSEC by some Latin American states, or the stopping of funding as a result of states refusing to sign agreements on the ICC. Whilst WHINSEC staff attribute this to lack of interest, it may also be that the shifting strategies in US foreign policy more broadly have had a knock-on effect upon the types of courses that the Department of Defence actually push in terms of advertising and recruitment, in line with their own changing priorities and increasing emphasis on counter-terrorism activities, rather than on democracy promotion and human rights strategies emphasised under the Clinton administration. ${ }^{119}$ Or it might be that Latin American states themselves are self-selecting the courses they opt for in response to US priorities in the region.

\section{Conclusion}

This paper has demonstrated that throughout the Cold War, SOA did condone and advocate repression. The notorious Spanish language manuals were not anathema to US foreign policy, but were typical of a CI strategy adopted by the US throughout the Cold War. WHINSEC, by contrast, is not engaged in encouraging students to violate international law, prioritising instead appropriate civil-military relations and respect for human rights. This is largely thanks to the efforts of SOAW. Neither has WHINSEC, as yet, played any part in the resurgence of support for repression that we have witnessed in the "War on Terror". The same cannot be said of the majority of US training of military forces from the South, or of the US' own military personnel. The remainder of the training is unaccountable, not required to incorporate the same high standard of human rights training that is present at WHINSEC, and increasingly being made available to countries with poor human rights

\footnotetext{
${ }^{114}$ Associated Press, 'Biographical Info on Supreme Court Candidate Ben Hand', Associated Press, 7 April2006, <http://www.al.com/newsflash/regional/index.ssf?/base/news-

20/114444686545500.xml\&storylist=alabamanews>; Western Hemisphere Institute for Security Cooperation, 'WHINSEC Board of Visitors', WHINSEC, 2006, <https://www.benning.army.mil/whinsec/BOV.asp?id=27>

${ }^{115}$ Edward Herman and Gerry O'Sullivan, The "Terrorism" Industry: The Experts and Institutions that Shape Our View of Terror, (New York: Pantheon, 1989), chapter 2.

${ }^{116}$ Marc Ambinder, 'Inside the Council for National Policy. Meet the Most Powerful Conservative Group You've Never Heard Of', ABC News, <http://abcnews.go.com/Politics/story?id=121170\&page=1> Accessed 16 March 2006.

${ }^{117}$ Personal correspondence with Professor Deborah Avant, 12 December 2005.

${ }^{118}$ Personal correspondence with Lee Rials, WHINSEC Public Affairs Officer, 30 April 2006.

${ }^{119}$ For a discussion of the differences between priorities under Clinton and since 9/11, see Grandin, 'The Wide War', <http://www.truthout.org/docs_2006/printer_050806L.shtml>
} 
records. In this sense, as opposed to WHINSEC, the remainder of the training is consistent with coercive elements of US foreign policy since 9/11. Even WHINSEC, following White House intervention in the selection of the Board, may cease to be so transparent, and may no longer be subject to the rigorous scrutiny that previous Board members insisted upon.

SOAW was crucial in forcing the re-launch of SOA, and to the introduction of extensive human rights training at WHINSEC. Nevertheless, they continue to campaign for its closure. Discussions with the SOAW leadership revealed that even they do not believe that WHINSEC poses any immediate threat to human rights. Roy Bourgeois said that he did not believe torture was being advocated, "but that if the campaign moved its focus away from the School, it would lose its campaigning flagship". ${ }^{120}$ Eric LeCompte, a member of SOAW staff also stated: "I believe we will close the school but I hope it won't be too soon so that we can build a movement to make the connections with foreign policy." "21 Many SOAW members continue to believe that WHINSEC is no different from SOA, and that it continues to pose a threat to human rights, despite the acknowledgement among SOAW's leadership that this is not the case. Conveniently for the DoD, attention remains on WHINSEC, diverting attention from the majority of US military training.

The US offers military training to states with poor human rights records, and the US itself has a poor human rights record. The majority of US military training, both for domestic and foreign personnel, is devoid of any credible human rights content. The current US administration is circumventing international law by sanctioning the repression of detainees in the "War on Terror." These policies undermine the progress made at WHINSEC, which represents just one percent of all US training of foreign military personnel. Rather than close WHINSEC, pressure should be put on the DoD to ensure that it remains transparent, and at the very least, that all other US military training initiatives are subject to the same level of external oversight. Those in receipt of training, whether US nationals or foreigners, should receive the same levels of human rights training as WHINSEC students. SOAW could focus on these issues, as well as on the question of whether the human rights training provided is effective. In addition, the administration should be challenged over its repressive practices in the "War on Terror", especially as such practices are likely to influence US training of military forces from the South.

\footnotetext{
${ }^{120}$ Interview with Father Roy Bourgeois at his office, situated outside the gates of Fort Benning, Columbus, Georgia, 20 July 2004.

${ }^{121}$ Interview with Eric LeCompte, Staff member, SOAW, SOAW Office, Washington DC, 16 July 2004.
} 